\title{
Effect of replacing maize and starch with Shoti meal (Curcuma zedoaria) in broiler
}

\author{
S Datta ${ }^{1}$, S Rahman ${ }^{1}$, O Islam ${ }^{1}$, M Hassan', M Hossain ${ }^{1}$, SMA Islam² and MH Rahman ${ }^{\text {* }}$ \\ ${ }^{1}$ Department of Pathology, Bangladesh Agricultural University, Mymensingh-2202, Bangladesh; ${ }^{1}$ Department of \\ Animal Science, Bangladesh Agricultural University, Mymensingh-2202, Bangladesh
}

\begin{abstract}
The effects of raw and autoclaved Shoti (Curcuma zedoaria) meal on the growth and $\mathrm{N}$ utilization of growing broilers were determined. Shoti from Bangladesh Agricultural University campus was collected and sorted on the basis of white color of the rhizome. Then they were chopped into pieces, sun dried and pulverized in a flour mill. Aliquot samples were autoclaved at $120^{\circ} \mathrm{C}$ under $15 \mathrm{lb}$ of pressure per square inch for $30 \mathrm{~min}$. Autoclaved samples were stored in tightly lid contained for future use. 3 One hundred -day-old Cobb 500 broiler chicks were reared on the floor and a total of 24 growing broilers, 4 birds in each group were weighed on d 15 Two broilers were placed in each cage. There were a total of four experimental and two control (positive and negative Non-protein control) diets. Diets were fed ad libitum from day 15 to 33days. Body weight, feed intake, feed refusal and fecal weights were recorded every day. Cumulative feed efficiency per bird was calculated as the ratio of weight gained to feed consumed. Dry matter of excreta was determined from the last $10 \mathrm{~d}$ of feeding trial by drying aliquots of every day's droppings by drying for $6 \mathrm{~h}$ at $105^{\circ} \mathrm{C}$. On d 19, birds were bled to death. Immediately after slaughter, the carcasses were examined systematically. The chemical composition of Shoti meal showed that it is low in protein, fat and trace minerals and therefore mainly a source of energy. The bulk of the tuber ( 75 percent) consists of carbohydrates, made up of $10.6 \%$ fiber, and $64.9 \%$ nitrogen free extracts (NFE). A peculiarity of Curcuma rhizome meal contains high level of ash (9.9\%) on DM basis. The results showed that at day 33 , the weight of the broiler chicken fed shoti $100 \mathrm{~g}, 200 \mathrm{~g}, 300 \mathrm{~g}$ and $200 \mathrm{~g}$ (autoclaved shoti meal)/ $\mathrm{Kg}$ diet was significantly different from the weight of the chicken fed on a maize-soybean diet. The birds given shoti meal consumed less feed than those provided with a maize diet. Feed efficiency or weight gain to feed ration over 19-d period was the poorest when fed $300 \mathrm{~g}$ Shoti/ $\mathrm{Kg}$ diet. Intake picked up when the shoti meal was incorporated after having been autoclaved and there was slight improvement in body weight gain as compared to that of other Shoti fed group. However, feed efficiency and body weight gain as $\%$ of initial weight remained significantly lower than the maize-soybean control. The inclusion of Shoti meal generally had an adverse effect on the apparent dry matter digestibility compared with the control diets. The group fed autoclaved shoti meal had a similar effect and the true $\mathrm{N}$ digestibility was the lowest when compared to those of control fed on maize-soybean meal. Thus, physical treatment like using autoclave, caused further reduction of digestibility of its N. Lipid digestibility was reduced by ingestion of shoti meal. Since the diets were isocaloric, after correction for the apparent endogenous lipid losses, which were obtained from the results of non-protein control feeding, the net faecal losses was around $66.2 \%$ of the ingested lipid against control diet fed birds.
\end{abstract}

Key words: feeding trial, broiler, Curcuma zedoaria, shoti

Bangladesh Animal Husbandry Association. All rights reserved. $\quad$ Bang. J. Anim. Sci. 2018. 47 (1):40-46

\section{Introduction}

Curcuma zedoariais, a starchy rhizomatous/tuberous from the Zingiberaceae family, commonly known as ginger family. "Ginger" is a general term for members or species of the ginger families. "Curcuma" is the genus name of the rhizomatous herb, of Zingiberaceae. They are widely grown in the East-Asian countries including China (called Erchu in Chinese), Vietnam, India, Bangladesh, Indonesia and Malaysia. It's root powder is a good commerce, is also known as Round zedoary substitute for many foreign foods for infants. The starch left after the extraction is

*Corresponding author: rahmanmdhabib@gmail.com 
purified and sold as a commodity of cottage industry in West-Bengal under the name 'Shoti'. In Bangladesh, shoti is used to be an indigenous baby food made from its root during 1970's. Carbohydrate research wing of the Bangladesh Council of Scientific and Industrial Research (BCSIR) laboratories have proved that the powdered tuberous root of 'shoti' can be used as a baby food. With large and fleshy tubers, which are rich in starch is highly valued as a diet for infants and convalescents. BCSIR scientists have experimentally shown that in addition to its high quality starch content, 'shoti' powder's quality can be further enriched by mixing it with cow milk, vitamin $A$ and $D$ and so on. The evolution of the food sector has increased interest in the identification of new starches with distinct properties. Curcuma longa and Curcuma zedoaria rhizomes, which are already used in industry to obtain food coloring and pharmaceutical products, may become commercially interesting as starch raw materials. Leonel et al (2003) characterized the starch of two Curcuma species. The results revealed that the rhizomes of two species showed low dry matter and high starch contents. The amylose contents of the starches ( $22 \%$ C. longa and $21 \%$ C. zedoaria) were similar to potato starch. Thus, aim of this study is to establish any anti-nutritional effects of Curcuma zedoaria (shoti) when it will be used as a source of food for the growing broilers and to determine whether its nutritional value is explainable in terms of its chemical composition. The effects of physical treatment like autoclaving of shoti meal and eventual safe incorporation in the broiler diet and thus on its nutritional quality has also been assessed.

\section{Materials and Methods}

\section{Shoti meal preparation}

Curcuma zedoaria (Shoti) from Bangladesh Agricultural University campus was collected and sorted on the basis of white color of the rhizome. Then they were chopped into pieces, sun dried and pulverized in a flour mill. Aliquot samples were autoclaved at $120^{\circ} \mathrm{C}$ under $15 \mathrm{lb}$ of pressure per square inch for $30 \mathrm{~min}$. Autoclaved samples were stored in tightly lid contained for future use. The procedure followed was essentially the as that used by Latif et al., (1979). Maize starch, corn oil, soybean meal, amino acids, minerals and vitamins were bought locally and were of general purpose grade. Test and control diets were formulated by substation of maize starch.
The composition of four test diets were shown in Table 1.

\section{Pre-experimental period}

100 Day-old Cobb 500 broiler chicks were obtained from local hatchery through a local agent in Mymensingh and were housed on rice husk until 14 day of age. They were fed commercial broiler starter diet ad libitum and reared on husk floor. Water was supplied ad libitum in plastic water trough. The body weight was monitored daily.

Figure 1. Growth curve for broilers fed ad libitum on reference control or test diets

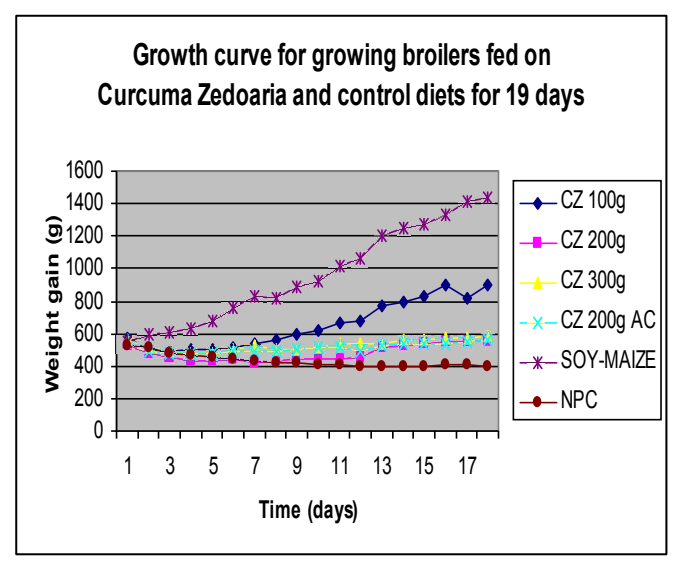

\section{Bird husbandry and sample collection}

A total of 24 growing broilers, 4 birds in each group were weighed on d $15 \mathrm{~d}$ weighing $525 \pm$ $18.4 \mathrm{~g}$, randomly allocated to cages. Two broiler birds were placed in each cage. There were a total of four experimental and two control (positive and negative Non-protein control) diets. Diets were fed ad libitum from day 15 for a period of $18 \mathrm{~d}$ (conventional slaughter weight). Body weight, feed intake, feed refusal and fecal weights were recorded every day. Cumulative feed efficiency per bird was calculated as the ratio of weight gained to feed consumed.

The number of chicks with sticky droppings adhering to the cloaca area was noted on the same days of excreta collection. Water was available ad libitum throughout the study, via water plastic trough. On d 19, birds were bled to death. Immediately after slaughter, the carcasses were examined systematically. The abdomen was opened and gut contents were flashed with $0.9 \%$ saline and the length the intestine was recorded. 
Table 1. The composition ( $\mathrm{gm} / \mathrm{kg}$ )of experimental diets for growing broilers

\begin{tabular}{lrrrrrr}
\hline \multicolumn{1}{c}{ Ingredients } & \multicolumn{2}{c}{ Control diets } & \multicolumn{4}{c}{ Experimental diets } \\
\cline { 2 - 7 } & $\begin{array}{l}\text { Maize- } \\
\text { Soyprotein }\end{array}$ & $\begin{array}{l}\text { Non- } \\
\text { protein } \\
\text { control }\end{array}$ & $\begin{array}{l}\text { Shoti } \\
(10 \%)\end{array}$ & $\begin{array}{l}\text { Shoti } \\
(20 \%)\end{array}$ & $\begin{array}{l}\text { Shoti } \\
(30 \%)\end{array}$ & \multicolumn{1}{l}{$\begin{array}{l}\text { Shoti } \\
(20 \%) \\
\text { autoclaved }\end{array}$} \\
\hline Shoti meal & 0 & 0 & 100 & 200 & 300 & 200 \\
Maize & 590 & 105 & 478 & 355 & 232.5 & 355 \\
Soya-bean meal & 358 & 0 & 353 & 355 & 353 & 355 \\
Maize oil & 15 & 147 & 32.10 & 53.1 & 78 & 53.1 \\
Di-calcium phosphate (DCP) & 28.8 & 0 & 28.5 & 28.3 & 28.3 & 28.30 \\
Sodium chloride & 3.7 & 3.0 & 3.7 & 3.70 & 3.7 & 3.70 \\
Vitamin-mineral premix & 3.0 & 10 & 3.0 & 3.0 & 3.0 & 3.0 \\
Methionine & 1.50 & 0 & 1.70 & 1.90 & 1.90 & 1.90 \\
Maize starch & 0 & 735 & 0 & 0 & 0 & 0 \\
\hline
\end{tabular}

\section{Analytical methods}

Dry matter of the dried Shoti meal was determined by drying at $100^{\circ} \mathrm{C}$ for 24 hours (AOAC, 1990), Total nitrogen (N) was determined by the Macro Kjeldahl method, ash was measured in a muffle furnace at $500^{\circ} \mathrm{C}$ for 18 hours. Further analyses were carried out in the Departments of Soil Science, Biochemistry and Animal Nutrition. Diets and droppings were pulverized in a hammer mill designed by Dr.M.H.Rahman, which was fitted with $1 \mathrm{~mm}$ sieve. Pulverized diets and droppings were analyzed for total N (Davidson et al., 1970). Crude fibre was determined according to the sequential analysis described by Robertson and van Soest (1981) and was carried out in the Department of Animal Nutrition. BAU, Mymensingh.

\section{Statistical analysis}

The results of the four individual bird of the ad libitum feeding experiments were pooled and statistical analysis was done by one-way ANOVA using the Minitab computer programme (Minitab Inc., State College, PA 1608, USA). When P values were $<0.05$, the significance of difference between groups were estimated by Student's t test.

\section{Results}

The chemical composition of Shoti meal was studied. It was found that DM, CP, CF, EE, NFE, ash and OM were 90.3, 8.05, 10.6, 6.5, 64.9, 9.85 and $90.2 \%$, respectively. It was shown that the shoti meal is low in protein, fat and trace minerals and therefore mainly a source of energy. The bulk of the tuber (75 percent) consists of carbohydrates, made up of $10.6 \%$ fiber, and $64.9 \%$ nitrogen free extracts (NFE). A peculiarity of Curcuma rhizome meal has shown to have contained a high ash content $(9.85 \%)$ Bird health was good throughout the study period and grew well without any extra additives. However, birds fed on diets containing Shoti meal were generally stunted and appeared to be lethargic. Sticky and wet droppings were especially in birds fed autoclaved shoti meal in their diet. There was no mortality and thus all the experimental and control groups completed the feeding trials. Nitrogen analysis of each diet revealed that the $\mathrm{CP}$ contents were similar to formulation, being in the range of 156 to $188 \mathrm{~g} / \mathrm{Kg}$. It appears from the present experiments that the body weight changes observed upon feeding of raw and autoclaved shoti meal grew in similar pace. However, the weight gain achieved on the nonprotein control diet as expected much less than those observed under ad libitum feeding condition. Furthermore, after 19 days, the birds on maize-soybean meal diet were heavier than any other groups. 
Datta et al. (2018) Bang. J. Anim. Sci. 47 (1):40-46

Table 2. Performance of Cob-500 birds fed ad libitum on Curcuma zedoaria (shoti) meal diets

\begin{tabular}{|c|c|c|c|c|c|c|c|}
\hline $\begin{array}{l}\text { Dietary } \\
\text { groups }\end{array}$ & $\begin{array}{l}\text { Non-protein } \\
\text { control (4) }\end{array}$ & $\begin{array}{l}\text { Control } \\
\text { Group } \\
(4)\end{array}$ & $\begin{array}{l}\text { Shoti-100 g/ } \\
\mathrm{Kg}(4)\end{array}$ & $\begin{array}{l}\text { Shoti- } \\
200 \mathrm{gm} / \quad \mathrm{Kg} \\
(4)\end{array}$ & $\begin{array}{l}\text { Shoti-200g } \\
\text { autoclave (4) }\end{array}$ & $\begin{array}{l}\text { Shoti-300g } \\
\text { (4) }\end{array}$ & P.S.D \\
\hline $\begin{array}{l}\text { Startin } \\
\text { g body } \\
\text { wt. (g) }\end{array}$ & $530.4 \pm 3.6$ & $555.3 \pm 37.2$ & $547.75 \pm 2.5$ & $525.5 \pm 3.2$ & $533.7 \pm 35.24$ & $533.6 \pm 3.6$ & 18.41 \\
\hline $\begin{array}{l}\text { Final } \\
\text { body } \\
\text { wt. (g) }\end{array}$ & $397.8 \pm 21.2$ & $1483 \pm 37.9$ & $904.6 \pm 33.6$ & $555.3 \pm 47.9$ & $579.5 \pm 48.9$ & $557.8 \pm 50.1$ & 41.7 \\
\hline $\begin{array}{l}\text { Weight } \\
\text { gain } \\
\text { (g) }\end{array}$ & -132.6 & 927.7 & 356.8 & 29.8 & 45.8 & 24.2 & \\
\hline $\begin{array}{l}\text { Total } \\
\text { feed } \\
\text { intake( } \\
\text { g)/ } 4 \\
\text { birds }\end{array}$ & 3,568 & 8,078 & 4,527 & 2,613 & 2,846 & 2,773 & \\
\hline $\begin{array}{l}\text { Feed } \\
\text { efficien } \\
\text { cy } \\
\text { (gain/ } \\
\text { feed/ch } \\
\text { icken) }\end{array}$ & - & 0.46 & 0.32 & 0.04 & 0.06 & 0.03 & \\
\hline $\begin{array}{l}\text { Body } \\
\text { weight } \\
\text { gain as } \\
\% \text { of } \\
\text { initial } \\
\text { weight } \\
\text { (g) }\end{array}$ & -25 & +167.1 & +65.2 & +5.7 & +8.6 & +4.5 & \\
\hline
\end{tabular}

\section{Bird performance}

The results summarized in Table 3 show cumulative data over the $19-d$ period of the feeding trials. Each value represents the Mean \pm SE for 4 birds. Analysis of variance for the above feeding trial reveals that at day 19 the weight of the broiler chicken fed shoti $100 \mathrm{~g}$, $200 \mathrm{~g}, 300 \mathrm{~g}$ and $200 \mathrm{~g}$ (autoclaved shoti meal)/ $\mathrm{Kg}$ diet was significantly different from the weight of the chicken fed on a maize-soybean diet. The birds given shoti meal consumed less feed than those provided with a maize diet. Feed efficiency over 19-d period was the poorest when fed $300 \mathrm{~g}$ shoti/ $\mathrm{Kg}$ diet. Intake picked up when the shoti meal was incorporated after having been autoclaved and there was slight improvement in body weight gain as compared to that of other Shoti fed group. However, feed efficiency and body weight gain as $\%$ of initial weight remained significantly lower than the maize-soybean control.

\section{Nutrient digestibility}

The inclusion of Shoti meal generally had an adverse effect on the apparent dry matter digestibility compared with the control diets (Table 1). Since, diets were iso-nitrogenous (except for non-protein control), the $\mathrm{N}$ intake of birds from meal based on raw shoti meal was consequently reduced by the same factor. In spite of this, $\mathrm{N}$ excretion in the droppings was significantly elevated in birds fed Shoti based diets. After correction for the apparent endogenous $\mathrm{N}$ losses, which were obtained from the results of non-protein feeding, the net dropping amounted to approximately $44.6 \%$ of the ingested in birds fed on autoclaved shoti meal against only $13.5 \%$ for the control diet fed group. Consequently, the inclusion of raw shoti meal in the diet drastically affected the $\mathrm{N}$ digestibility. It was approximately half of the calculated for the diet where maize-soybean meal was used. The group fed autoclaved shoti meal had a similar effect and the true $\mathrm{N}$ digestibility was the lowest when compared to those of control fed on maize-soybean meal. Thus, physical treatment like autoclaving caused further reduction of digestibility of its $\mathrm{N}$.

Lipid digestibility was reduced by ingestion of shoti meal. Since the diets were iso-caloric, after correction for the apparent endogenous lipid losses, which were obtained from the results of non-protein control feeding, the net faecal losses was around $66.2 \%$ of the ingested lipid against control diet fed birds. 


\section{Discussion}

The present research contains a description of using some anti-nutritional effects of Curcuma zedoaria (shoti) in growing broilers. The aim was to determine nutritional quality of shoti meal which was regarded as one of the naturally grown carbohydrate sources. The feed intake and growth rates obtained from feeding diets based raw and autoclaved shoti meal were significantly lower than those found with control diet. These findings were similar to those made previously with rats and chicks given diets based on shoti (Latif et al., 1979). This low feed intake could have been due to the presence of anti-nutritional factors, such as lectins or flatus glycosides in the meal (Cheeke and Kelly, $1989)$. The high ash content $(9.85 \%)$ primarily represents the amount of minerals that has occurred in the meal. The biggest negative effect of high ash content is that it dilutes the nutrient content of the feed. Therefore, birds tend to eat less of the high ash shoti meal, a matter needs to be confirmed (Cross, 1978). Feed intake has been found in part to be hormonally regulated with cholecystokinin (CCK) being an important component in eliciting satiety (Baile et al., 1986). Trypsin inhibitors or high levels of undigested protein or partly digested protein in the intestinal lumen have been shown to induce secretion of CCK (Liener, 1989). Through interference with the negative feed-back signal, its production is known to be increased by trypsin inhibitors (Pusztai, 1966). Thus, CCK has been suggested to be a satiety peptide (Anika et al., 1981) and thus it is possible that any in in its luminal concentration as a result of any plant anti-nutrient like trypsin inhibitor(s), would lead to a reduced feed intake. Boonmee et al., (2011) found out biologically active proteins from Curcuma comosaRoxb rhizome from Thailand and considered as lectins (Pusztai., 1994).

The amino acid sequences of Curcuma lectins were identical to the lectins from Allium sativum and Gastrodiaelata. These two lectins are quiet different in size, being 33.9 and $18.1 \mathrm{kDa}$, respectively, with the smaller being in $\sim 15 \mathrm{kDa}$. In addition, alpha-glucosidase inhibitory activity also was found in this plant. These workers were also of the opinion that Curcuma rhizome would be rich in other non-alpha-glucosidase inhibitory proteins, and so the actual protein inhibitor(s) specific activity is likely to be significantly higher. It is therefore possible that either of these factors would have led to significantly increased CCK production and elicit satiety. Furthermore, dietary lectins have also been shown to reduce food intake (Grant, 1989).

Harper et al (1970) showed that feed intakes of rats offered diets in which there was a large amino acid imbalance have been found to be very low compared to those of rats fed on diets with a balanced amino acid profile. Latifet., 1979) from their rat and poultry feeding trials had indicated that shoti protein should be of reasonable quality, though it contained somewhat less lysine than soybean-protein. It is potentially valuable as a source of protein for humans and animals.

Table 3. Comparison of $\mathrm{N}$ and lipid losses in broiler growers fed on Curcuma zedoaria and control diets

\begin{tabular}{|c|c|c|c|c|c|c|}
\hline Dietary groups & $\begin{array}{l}\text { Non- } \\
\text { protein } \\
\text { control } \\
(4)\end{array}$ & $\begin{array}{l}\text { Control } \\
\text { Group } \\
(4)\end{array}$ & $\begin{array}{l}\text { Shoti-100 g/ } \\
\mathrm{Kg}(4)\end{array}$ & $\begin{array}{l}\text { Shoti- } \\
200 \mathrm{gm} / \\
(4)\end{array}$ & $\begin{array}{l}\text { Shoti-200g } \\
\text { autoclave (4) }\end{array}$ & $\begin{array}{l}\text { Shoti-300g } \\
\text { (4) }\end{array}$ \\
\hline $\begin{array}{l}\text { Intestinal length } \\
(\mathrm{cm})\end{array}$ & - & $163.25 \pm 7.6$ & $158.75 \pm 2.63$ & $141.0 \pm 5.2$ & $122.5 \pm 3.7$ & $131.0 \pm 7.30$ \\
\hline $\begin{array}{l}\text { Intestinal length } \\
\text { (cm/ } 100 \mathrm{~g} \text { live } \\
\text { body weight) }\end{array}$ & - & 11.00 & 17.6 & 25.4 & 21.1 & 23.3 \\
\hline $\mathrm{N}$ intake (\%) & 0.54 & 3.86 & 3.0 & 2.72 & 2.86 & 2.50 \\
\hline $\mathrm{CP}(\%)$ & 3.34 & 24.12 & 18.75 & 17.0 & 17.90 & 15.62 \\
\hline $\begin{array}{l}\text { True N } \\
\text { digestibility (\%) }\end{array}$ & & 59 & 37 & 34 & 22 & 32 \\
\hline $\begin{array}{l}\text { DM digestibility } \\
(\%)\end{array}$ & & 65 & 41 & 37 & 24 & 35 \\
\hline $\begin{array}{l}\text { Fecal N excretion } \\
(\%)\end{array}$ & 1.62 & 2.14 & 2.42 & 2.34 & 2.78 & 2.24 \\
\hline Fat intake (\%) & 6.78 & 9.80 & 15.40 & 12.50 & 14.90 & 10.90 \\
\hline $\begin{array}{l}\text { Fat excretion } \\
(\%)\end{array}$ & 10.80 & 2.40 & 16.0 & 13.90 & 14.0 & 14.90 \\
\hline $\begin{array}{l}\text { True lipid } \\
\text { excretion (\%) }\end{array}$ & & & 5.2 & 3.1 & 3.2 & 4.1 \\
\hline
\end{tabular}


However, feeding to animals may be toxic since incorporation of $400 \mathrm{~g}$ shoti flour/ $\mathrm{Kg}$ diet resulted deaths in rats. Part of the effect might have been due to the inclusion of the starch in the diet. However, shoti meal had a more dramatic effect on weight. Feed intake recorded for shoti meal diet was so low that simple starvation might have explained the loss of body-weight, but possibility of underlying pathological changes could not have been ruled out. Shoti meal was found to be deficient in methionine and would be the first limiting amino acid per se for poultry. Thus, methionine was added to the diet. Nevertheless, the poor feed consumption by birds given raw shoti meal was not primarily due to the imbalanced amino acid profile of the diet. Indeed, the finding that heat treatment (autoclaving) of raw shoti meal increased feed intake considerably but the digestibility was found to be the poorest as compared to those of control.

Faecal $\mathrm{N}$ outputs of birds given shoti meal increased significantly. This faecal nitrogen could have been derived partly from undigested dietary proteins, since shoti meal contains high dietary fibre $(10.5 \%)$ which may prevent digestible materials being hydrolysed by digestive enzymes. Alternatively, it could have been derived from endogenous sources such as digestive enzymes, mucus, shedding of gut cells, bacteria and leakage of serum proteins into the gut lumen. Excretion of $\mathrm{N}$ derived from these endogenous sources can be stimulated by a number of anti-nutritional factors (Pustai, 1987).

The reduced utilization of the absorbed $\mathrm{N}$ may in part have been a result of low availability of methionine or other amino acids caused by poor digestion of the dietary protein. Alternatively, it may have been due to changes in systemic intermediary metabolism which led to a higher rate of catabolism of amino acids and thus increased excretion of $\mathrm{N}$ and could be originated from a number of diverse factors such as:

a. undigested dietary proteins due to either their refractory nature or to the presence of protease inhibitors,

b. increased secretion of digestive enzymes due to the increase in undigested proteins in the lumen and the presence of protease inhibitors,

c. increased mucus secretion,

d. increased shedding of intestinal cells,

e. leakage of plasma protein into the lumen, or

f. over growth of bacteria
Lipid deposition by birds on different levels of shoti meal was significantly less than that occurred in birds given control protein diet. This may have been a result of malabsorption of dietary lipid and or change in intermediary metabolism which caused reduced accumulation of body lipid.

\section{Conflicts of interest}

We, the affiliated authors whose names are mentioned in the manuscript, hereby, clearly certify that, we have NO affiliations with or involvement in any organization or entity with any financial interest or non-financial interests in the subject matter or materials discussed in this manuscript.

\section{Conclusion}

The shoti meal has a negative impact on birds performance, when fed as a sole source of protein. Its ingestion appeared to result in poorer than expected in digestion, absorption of dietary protein and lipid and to cause disturbance of the intermediary metabolism. Such systemic effects lead to significant body compositional changes within 19 days.

\section{References}

AOAC (1990). Official methods of analysis (15th ed.). Association of Official Analytical Chemists, Washington DC, USA.

Baile CA, CL Mclaughlin and MA Della-fera (1986) Role of eholecystokinin and opioid peptides in control of food intake. Physiological Reviews 66: $172-234$.

Boonmee A, C Srisomsap, A Karnchanatat and P Sangvanich (2011). An antioxidant protein in Curcuma comosa Roxb. Rhizomes. Food Chemistry 124:476-480.

$10.1016 /$ j.foodchem.2010.06.057

Cross DL (1978). Efficacy of broiler litter silage for beef steers. Journal of Animal Science 47: 544.

Davidson J, J Mathieson AW Boyne (1970). The use of automation in determining nitrogen by the kjeldhal method, with Đnal calculations by computer. Analyst 95 181È193.

Grant G (1989). Antinutritional effects of soyabean: a review. Progress in Food and Nutrition Science 13: 317-348.

Harper $A E, N J$ Benevenga and $R$ M Wohlhueter (1970). Effects of ingestion of disproportionate amounts of amino acids. Physiolological Reviews 50:428-558.

Latif M, T Morris, A Miah, D Hewitt and J Ford (1979). Toxicity of shoti (Indian arrowroot: Curcuma zedoaria) for rats and chicks. British Journal of Nutrition 41(1): 57-63. doi:10.1079/BJN19790012 
Leonel M, SBS Sarmento and MP Cereda (2003). New starches for the food industry: Curcuma longa and Curcuma zedoaria. Carbohydrates Polymorphism 54: 385-388.

Liener IE (1989). Antinutritional factors in legume seeds: the state of the art. In: Recent Advances of Research in Antinutritinal Factors in L egume Seeds, ed Husiman J, van der Poel A F B \& Liener I E. Pudoc, Wageningen, The Netherlands, pp 6-13.

Pusztai A, G Grant, S Bardocz, E Gelencser and G Hajos (1997). Novel dietary strategy for overcoming the anti nutritiional effects of soyabean whey of high agglutinin content. British Journal of Nutrition 77: 933-945.
Pusztai A, G Grant, TJ Duguid, DS Brown, WJ Peumans, EJM Van Damme and $S$ Bardoc (1995). Inhibition of starch digestion by aamylase inhibitor reduces the efficiency of utilisation of dietary proteins and lipids and retards the growth of rats. Journal of Nutrition 125: 1554-1562.

Pusztai A (1966). The isolation of two proteins, Glycoprotein I and a trypsin inhibitor from the seeds of kidney bean (Phaseolus vulgaris). Biochemistry Journal 101: 379-385.

Robertson, JB and PJ Van Soest (1981) The detergent system of analysis and its application to human foods. In The Analysis of Dietary Fiber in Food pp. 123158 [James, WPT, and Theander, $\mathrm{O}$ editors]. New York, NY: Marcel Dekker. 